\title{
Ohlédnutí za první štací výstavy Račte vstoupit do divadla ${ }^{1}$
}

Markéta Trávničková

Račte vstoupit do divadla

Národní muzeum -

Historické muzeum Institut umění -

Divadelní ústav

Moravské zemské muzeum

Hlavní autorka:

Markéta Trávníčková

Autorský tým: Jaroslav

Blecha, Alena Jakubcová,

Vojtěch Poláček,

Václav Štěpán, Markéta

Trávníčková, Libor

Vodička, Kryštof Vanča

Autorský tým doprovodné

výstavy ve Stavovském

divadle: Jitka Ludvová,

Milan Pospíšil

Kurátorky výstavy:

Kateřina Musílková,

Markéta Trávníčková

Produkce: Martin Musil,

Barbora Belzová, Markéta

Truncová

Architektonické řešení:

Tomáš Bílek

Grafika: Ondřej Zámiš

1 Tato stat' vznikla za finanční podpory Ministerstva kultury C $R$ v rámci projektu Cesta $k$ divadlu. Vývoj metodiky a specifických nástrojů pro uchování, exploataci a zprístupnění historických divadelních ceduli se zvláštním zřetelem ke sbírkovým fondùm Národního muzea v Praze a Moravského zemského muzea v Brně, podpořeného Programem aplikovaného výzkumu a vývoje národní a kulturní identity (NAKI II), č. DG16P02B008 (2016-2020).

Mgr. Markéta Trávničková Národní muzeum marketa.travnickova@nm.cz

\section{Looking back at the first stand of the exhibition Please Enter Our Theatre}

Abstract: The traveling exhibition Please Enter Our Theatre and its respective exhibition catalogue represent a theatre playbill as a valuable subject of theatriological research as well as an attractive exhibit. The exhibition shows the theatre scene in the Czech lands from the mid-1600s to the mid-1900s, when the playbills have experienced the most wide-spread use, with overlaps to the present, when a theater poster took most of the playbill's purposes upon itself. The exhibition also includes other objects pertaining to the productions of mostly Czech theatre companies from the vast collections of the National Museum's Theatre Department, such as photographs, manuscripts, stage and costume designs, props, stage models, paintings, busts, costumes or puppets.

Keywords: National Museum - Exhibition - Czech Theatre - Theatre Playbills

\section{Divadelní cedule, ústřední předmět výstavy Račte vstoupit do divadla}

Výstava Račte vstoupit do divadla vychází z polozapomenutého fenoménu inscenační praxe 19. a první poloviny 20. století, divadelních cedulí. Ukazuje jejich obsahový i formální vývoj a všechny funkce, které cedule plnily a plní: ve své době sloužily jako pozvánka na představení a často i jako umělecký artefakt, v současnosti jsou jedinečným, možná nejcennějším pramenem pro studium divadelní historie. Záznamy na nich totiž informují do nejmenších podrobností o všech základních údajích jednotlivých představení. Jedině na základě nich lze proto zpětně sestavit soupisy repertoárů divadel, přehledy inscenací, inscenátorů (režisérů, dirigentů, choreografů) či rolí herců.

Do dnešní doby si u nás bohužel uchovalo tuto tradici jen několik divadel, v Praze pouze Národní divadlo, v Čechách plzeňské divadlo, osvícenější jsou $\mathrm{v}$ tomto smyslu na Moravě - v Brně, Olomouci, Ostravě. Materiály, které je jinde nahradily, tedy divadelní programy, popřípadě vývěsky s programem na týden či měsíc, mohou být při rekonstrukci repertoáru využity jen v omezené míře (neznáme přesná data představení, nezjistíme, který herec kdy v roli vystoupil apod.).

\section{Výstava jako jeden z výstupů roz- sáhlého grantového projektu}

V posledních letech si význam divadelních cedulí pro badatele čím dál víc začínají uvědomovat i teatrologové $\mathrm{v}$ zahraničí. Vznikají databáze cedulí zejména na německých a rakouských pracovištích, přičemž nejdále je vídeňský Don Juan Archiv, který vydal na toto téma dvě výpravné publikace vědeckých studií. ${ }^{2}$ Všechny tyto výzkumy se ale důsledně drží znění předlohy, ambicí našeho projektu, který řešíme spolu s Institutem umění - Divadelním ústavem a Moravským zemským muzeem $\mathrm{v}$ rámci grantu Ministerstva kultury NAKI II, je údaje z cedulí ověřovat a korigovat pomocí dobových pramenů a odborné literatury. Výsledkem grantu je i metodika práce s cedulemi, tedy digitalizace, restaurování, vytěžení dat a jejich vkládání do specializované databáze, která by mohla sloužit dalším zájemcům o zpracování těchto pramenů. Zároveň vznikla specializovaná 
Zdařilá výstava z fondu sbírek Národního muzea týkající se českého divadla, založená především na neokázalém předmětu, jakým je divadelní cedule, zasluhuje velkou pochvalu. Cedule, která informuje o tom, co se hraje, kde a s kým; jak prosté a přesto významné. Zahajuje totiž rozpravu o fenoménu divadlo velmi prozaicky, ale zato autenticky! A v naší virtuální době je tato vlastnost nad jiné důležitá. Otvírá cestu $\mathrm{k}$ dějinám divadla prímo $\mathrm{u}$ pramene. Takže kdo má divadlo rád, přišel výstavou Račte vstoupit do divadla k potěšení objevovat, porozumět, zavzpomínat. Doplněním cedulí některými kostýmy z inscenací, rukopisy, předměty, fotografiemi, zkrátka svědky divadelní historie obrozenecké až novodobé, podala výstava ucelený obraz, jakou roli divadlo hrálo a jak vychovávalo i bavilo.

Kolik úsilí celý projekt stál, si umí představit asi jen teatrolog nebo vůbec historický badatel. A tým Mgr. Markéty Trávníčkové obstál na jedničku. Díky!

\section{Milena Dosoudilová, muzikoložka}

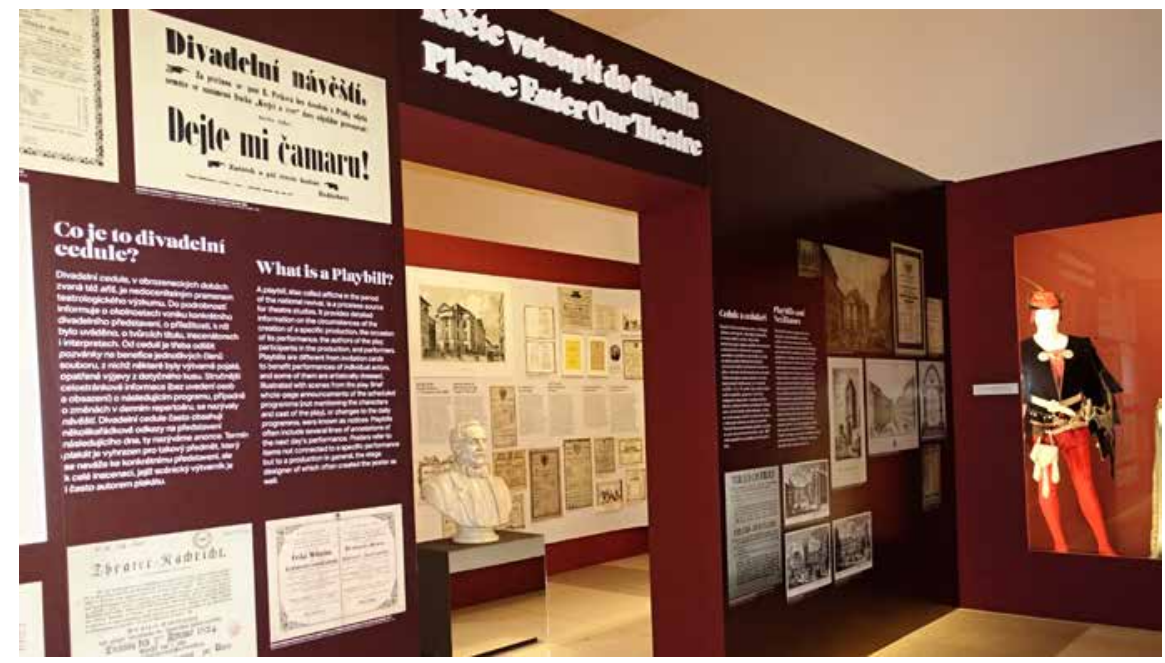

mapa ${ }^{3}$, prezentovaná i na výstavě, která představuje 160 institucí v Čechách a na Moravě, uchovávajících divadelní cedule. Ve sbírce Divadelního oddělení Národního muzea se nachází na 400000 těchto předmětů.

Neopomenutelnými výstupy grantu byly dvě k výstavě vydané doprovodné publikace. První je obrazová brožura pro běžné návštěvníky ${ }^{4}$, druhou výpravný katalog ${ }^{5}$, jehož editorkou je přední česká teatroložka Jitka Ludvová a který obsahuje vedle soupisu exponátů, představení projektu a fondů cedulí na příslušných pracovištích čtyři odborné divadelněhistorické studie a jedenáct článků z cyklu Cedule s př́iběhem. Doplněn je podrobným německým a anglickým resumé.

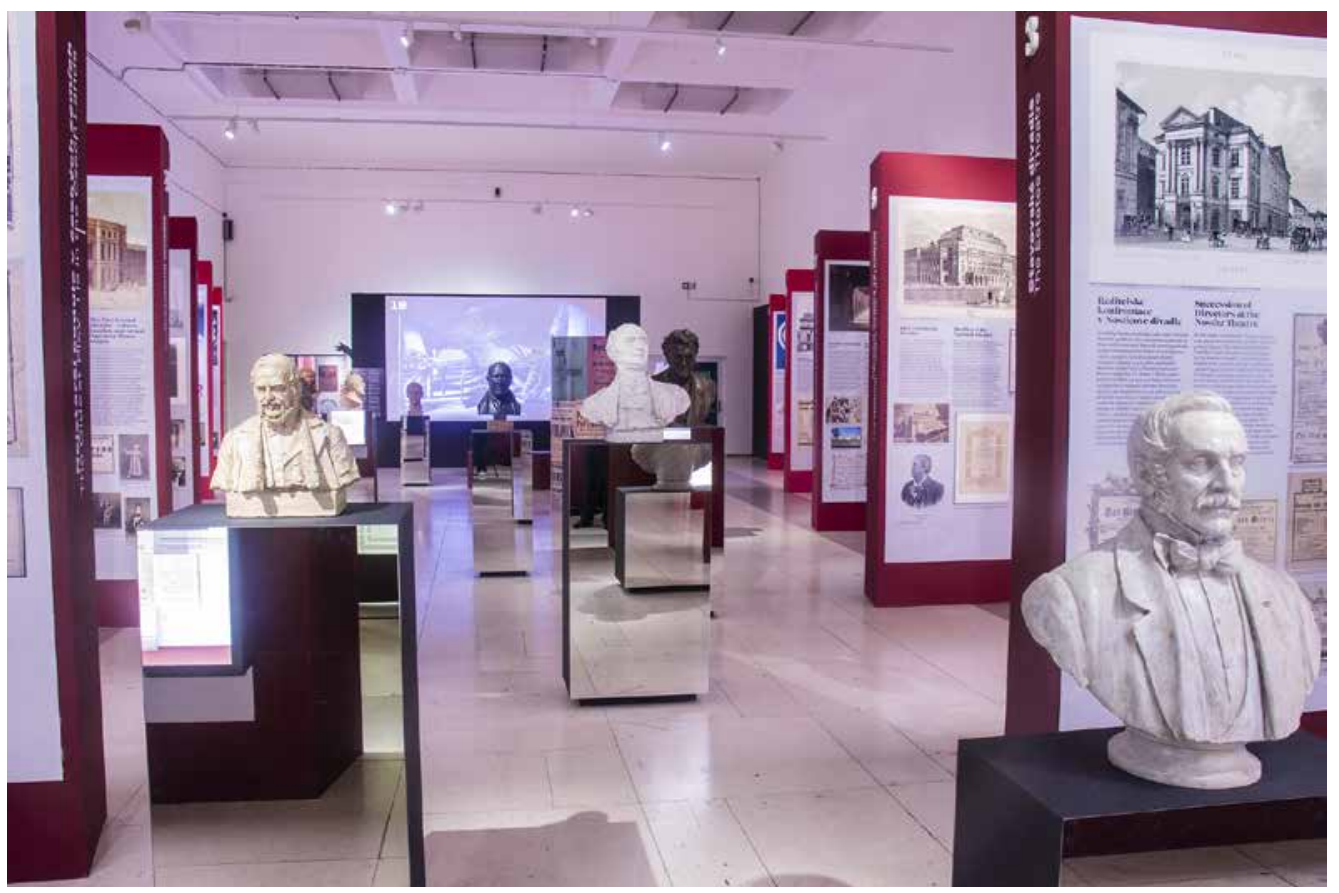

2 Theater - Zettel Sammlungen. Erschliessung, Digitalisierung,

Forschung. Ed. Matthias J. Pernerstorfer. Wien: Hollitzer Wissenschaftsverlag, 2012.

Theater - Zettel -

Sammlungen. 2.

Bestände, Erschließung, Forschung. Ed. Matthias J. Pernerstorfer. Wien: Hollitzer Wissenschaftsverlag, 2015. 3 www.divadelnicedule.cz 4 Račte vstoupit do divadla. Ed. Markéta Trávníčková. Praha: Národní muzeum 2019, $32 \mathrm{~s}$.

5 Račte vstoupit do divadla. Ed. Jitka Ludvová. Praha: Institut umění - Divadelní ústav a Národní muzeum, 2019, $278 \mathrm{~s}$. 


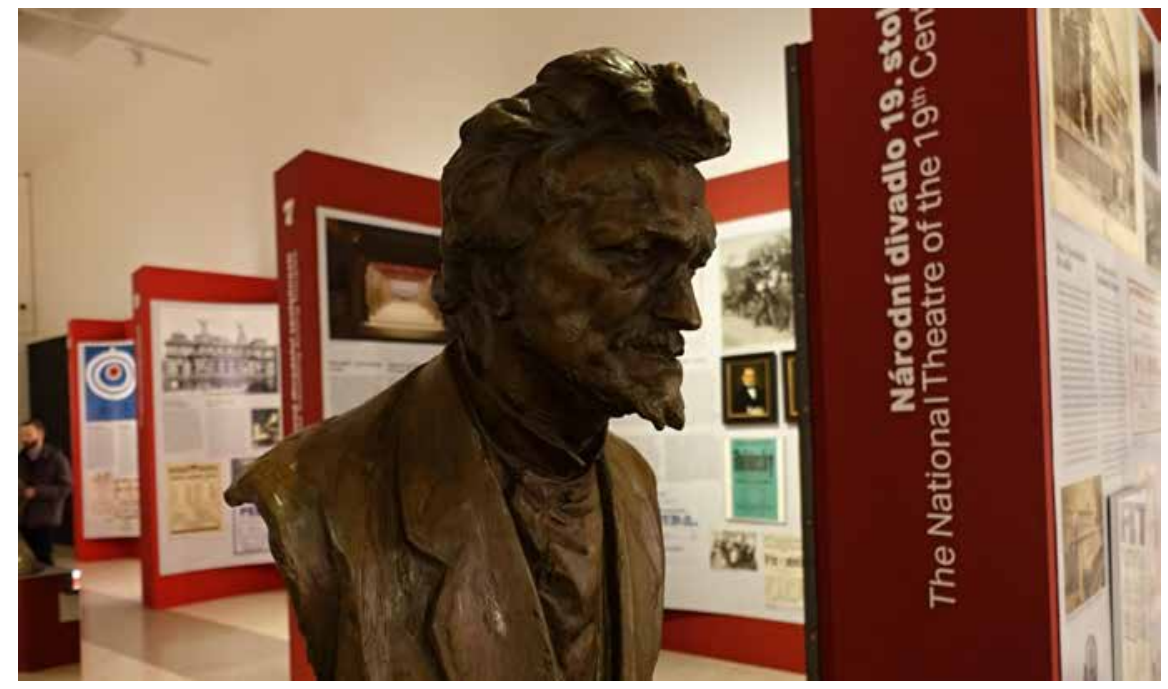

\section{Výstava jako stručný přehled české divadelní historie}

Výstava Račte vstoupit do divadla ukazuje proměnu cedulí od poloviny 17 . století, kdy vznikaly první periochy ${ }^{6}$ rádových divadel, do poloviny 20. století, kdy divadla začala praxi cedulí opouštět, ale $\mathrm{s}$ přesahy až do současnosti, hlavně v podobě divadelního plakátu. Plakáty se od cedule liší tím, že se nevztahují $\mathrm{k}$ jednotlivým představením, ale k celé inscenaci, funkci mají víc apelativní a estetickou než obsahovou.

Ambicí výstavy je zároveň podat obraz divadelního života $\mathrm{v}$ českých zemích daného období. Cedule jsou proto vedle vysvětlujících textů doprovozeny dalšími atraktivními exponáty, které ilustrují divadelní tvorbu - scénickými a kostýmními návrhy, fotografiemi, vzácnými rukopisy a tisky, realizovanými kostýmy, modely scén, rekvizitami, obrazy a bustami. Důraz je

6 Periochy neboli synopse, předchůdci cedulí v dnešním slova smyslu, obsahovaly nikoli osoby a obsazení, ale stručné obsahy děje. Nejstarším předmětem sbírky cedulí Divadelního oddělení Národního muzea a zároveň jeden z nejstarších predmětů celé divadelní sbírky je česky psaná periocha Constantinus z nezjištěného řádového divadla z roku 1642.
Celý svůj profesní život jsem strávila v Archivu Národního divadla. V archivu, který má to štěstí, že uchovává kompletní konvoluty divadelních cedulí za celou éru trvání Národního divadla a všech jeho scén. Záhy jsem pochopila, že je to to nejcennější, co vlastní. A že v případě katastrofy by to bylo to první, co bych zachraňovala. Bez tohoto základního a nejdůležitějšího historického pramene speciálně pro dějiny divadla bychom nikdy o divadle nevěděli tolik, kolik víme. Nápad vytvořit výstavu především $\mathrm{z}$ divadelních cedulí mě potěšil a jeho realizace mě nadchla. Navíc je výstava nápaditě doplněna dalšími divadelními a literárními artefakty. Libreta, rukopisy her, kostýmní a scénické návrhy, modely scén, režijní knihy, fotografie, listinné dokumenty, výtvarné plakáty - to vše dokresluje pohled návštěvníka na určité etapy divadelní tvorby nejen $\mathrm{v}$ hlavních městech Čech, Moravy a Slezska. Potěšilo mě, že se také připomněly kočovné společnosti a zámecká divadla. Pro dětské návštěvníky přináší př́ijemné odlehčení dětská část. A pokud si návštěvník při odchodu z výstavy koupí - za velmi př́jemnou cenu - doprovodnou publikaci, získá bonus navíc. Bude vlastnit krásnou knihu s pěknými reprodukcemi, spoustou dalších informací a skvělými odbornými studiemi. Gratuluji hlavní autorce Markétě Trávníčkové, celému autorskému týmu a všem, kteří se na výstavě Račte vstoupit do divadla podíleli. Vstoupila jsem, ledacos jsem se dozvěděla a měla jsem radost.

\section{Zdena Benešová, teatroložka}

kladen na divadla, jejichž historii máme díky cedulím zmapovanou den po dni, tedy pražské Stavovské, Prozatímní a Národní divadlo od roku 1824 dosud, vinohradské divadlo od založení v roce 1907 do roku 1959 nebo brněnské Národní divadlo z let 1892-1985. Ne souvislá, ale rozsáhlá je sbírka cedulí kočovných 
Výstava Račte vstoupit do divadla je výjimečným výstavním projektem. Jen těžko si lze asi představit méně atraktivní výstavní artikl, než je divadelní cedule, a přece autory inspirovala k vytvoření komunikující expozice, která srozumitelně vypráví př́běh českého divadelnictví. Akcent na tradiční „highlighty“ prrispívá k široké srozumitelnosti a umožňuje ukázat největší poklady sbírky Divadelního oddělení Národního muzea.Výstava přitom nezaostává za moderními trendy: její architektura upomíná $\mathrm{v}$ půdorysu na tradiční kukátkové jeviště, nápovědní budka je vtipně využita ke skrytí projektoru; nechybí dětský koutek; interaktivní mapa pak prozrazuje, že výstava je jen špičkou ledovce. Tím je totiž olbřímí a pro badatele nedocenitelná práce, kterou tým teatrologů vykonal, když evidoval divadelní cedule roztroušené po nejrůznějších sbírkách v ČR. Nedílnou součástí výstavy je obsáhlý katalog s řadou odborných textů a prrípadových studií, jaký by neměl chybět žádnému podobně koncipovanému projektu.

Petra Ježková, teatroložka

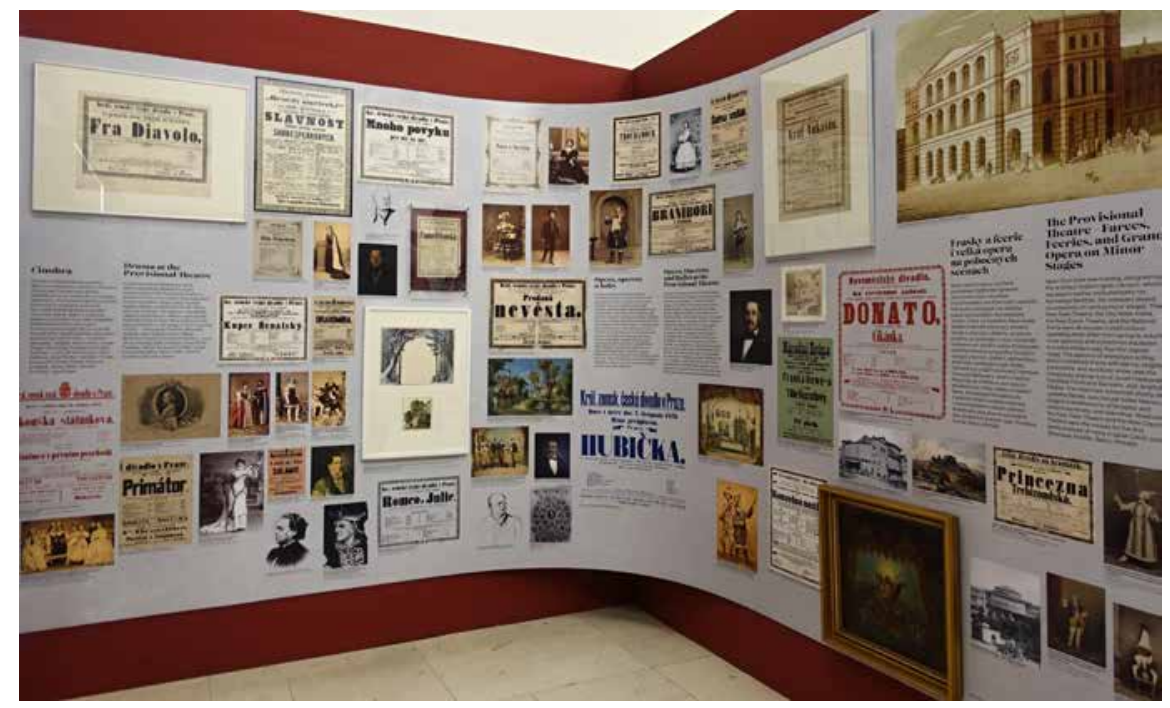

divadelních společností. Představujeme též meziválečná avantgardní divadla, zámecká a loutková divadla, jedna kóje (divadelní lóže) je věnována ceduli a plakátu jako uměleckému artefaktu.

Návštěvníkovi byl předložen reprezentativní výběr exponátů $\mathrm{z}$ bohatých fondů Divadelního oddělení Národního muzea, které dostalo šanci po mnoha letech souborněji představit své poklady. Jeho sbírkové předměty tvoří gros výstavy. Doplňují je zápưjčky z dalších muzejních oddělení (Oddělení starších českých dějin, Knihovna Národního muzea, České muzeum hudby) a z Oddělení dějin divadla Moravského zemského muzea. V kójích věnovaných divadlu $\mathrm{v} 17$. a 18 . století a moravským scénám jsme nejvíc využili rešerší, provedených $\mathrm{v}$ rámci tvorby specializované mapy v desítkách českých a moravských pamětových institucí - muzeích,

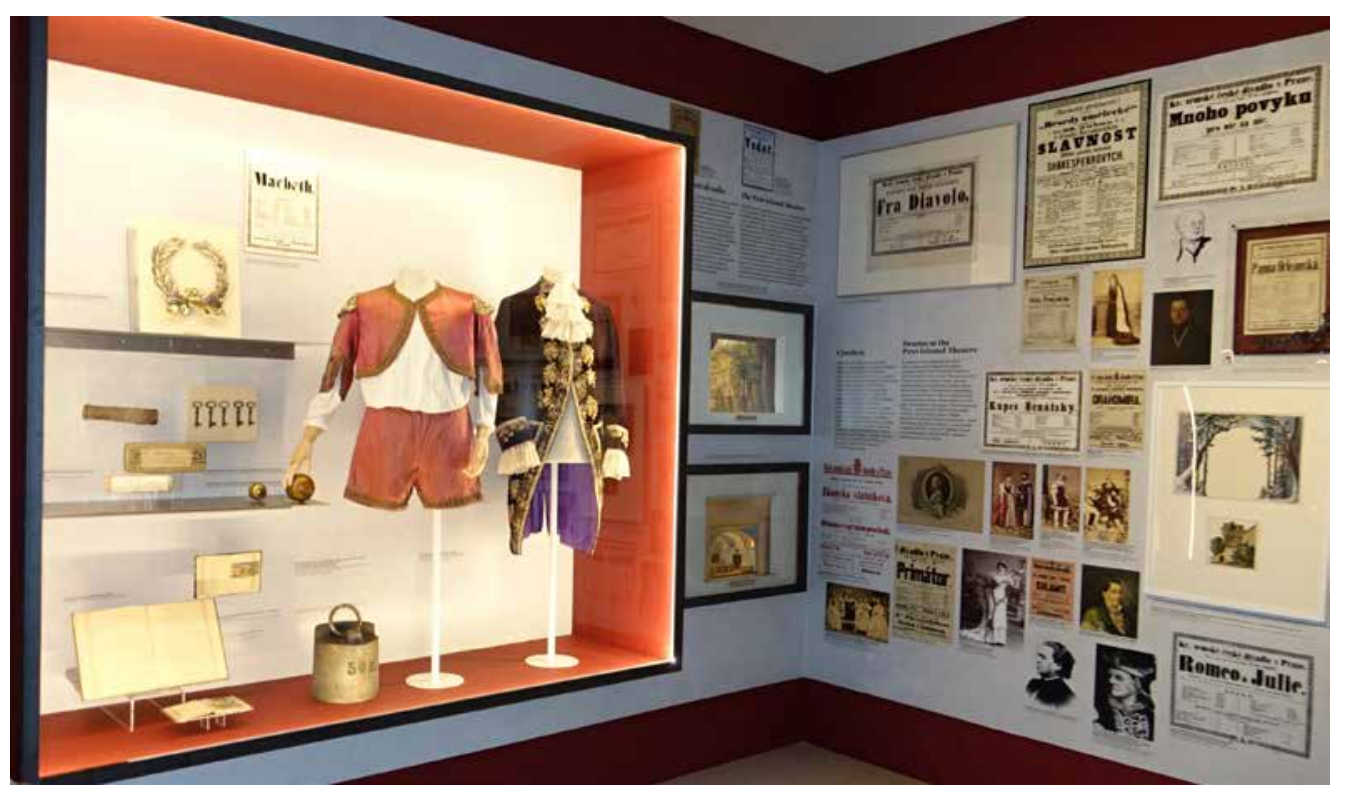


archivech, knihovnách. Poprvé byly vystaveny i nově objevené předměty ze 17. a 18. stoletî ${ }^{7}$, nalezené v pozůstalosti historika Jana Vondráčka ${ }^{8}$.

V Národním muzeu bylo vystaveno 1122 exponátů, $\mathrm{z}$ toho 186 originálních, 602 v kopiích a 334 ve videoprojekcích; 130 exponátů $\mathrm{z}$ tohoto počtu bylo umístěno $\mathrm{v}$ doprovodné výstavě ve Stavovském divadle, věnované domácím i zahraničním osobnostem, spojeným s tímto divadelním domem.

Putovní verze výstavy, zredukovaná zhruba o třetinu exponátů, je od května do zárí k vidění v Muzeu české loutky a cirkusu

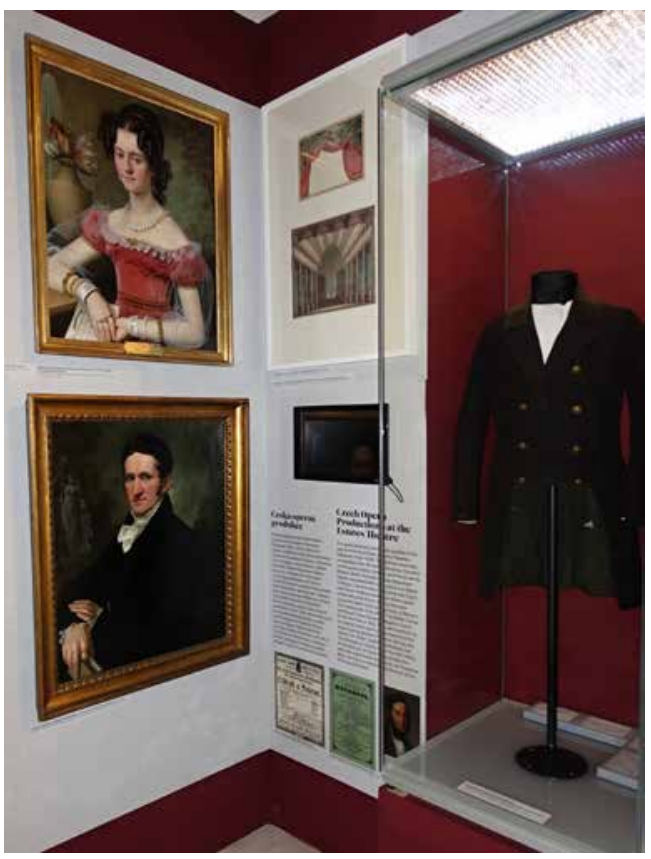

7 Periocha $k$ predstavení Laurentius Justinianus z chomutovského jezuitské koleje z roku 1654 nebo programový sešit $k$ představení Šporkovského divadla z roku 1713.

8 Viz Magdaléna Jacková, Alena Jakubcová, Jitka Ludvová, Markéta Trávníčková: Poklady v pozůstalosti Jana Vondráčka. Divadelní revue 29, 2018, č. 2, s. 45-66.
Výstava ze sbírek Divadelního oddělení Národního muzea je podle mého názoru zdařilým počinem, jenž dobře obstojí před očima malých i velkých zájemců jak z řad domácí kulturní veřejnosti, tak i teatrologů - specialistů na historii českého divadla. Tvoří ji množství vystavených exponátů, připomínajících vrcholy dobových jevištních produkcí a jako celek podává $\mathrm{v}$ chronologickém uspořádání a širokém žánrovém záběru esenciální obraz domácího divadelního dění u nás od 17. stol do poloviny 20. století. K výstavě byl vydán přehledný a cenný katalog.

Dnes, kdy tolik usilujeme o co největší exaktnost našich poznatků z nejrůznějších sfér vědeckého i uměleckého života, prozrazuje koncepce i uspořádání výstavy, že jejím jádrem je rozsáhlý vědecký výzkum jedinečné sbírky cedulí Divadelního oddělení jako jednoho z mála skutečně autentických zdrojů informací o divadelním umění dob minulých. Myslím, že se s tak zodpovědným př́stupem $\mathrm{k}$ divadelní složce národní kultury může pochlubit jen málokteré evropské divadelní muzeum. Díky své pestrosti je výstava nejen vkusně uspořádaná a svým způsobem i zábavná, ale může současně dobře posloužit ve smyslu posílení vědomí o společenském významu, jaký u nás divadelní umění vždy mělo. Nejde jen o jeho smysl estetický a politický, stačí se zaměřit třeba jen na jazykovou podobu vystavených cedulí, abychom si uvědomili složitost procesů, jimiž česká kultura minulých staletí procházela. Protože je výstava jen výběrem $\mathrm{z}$ bohatství divadelní sbírky Národního muzea, uvědomuji si oprávněnost někdejších snah mnoha českých teatrologů o založení specializovaného divadelního muzea.

Ladislava Petišková, teatroložka

v Prachaticích. Z důvodu koronavirové pandemie již bylo zrušeno plánované otevření výstavy v Moravském zemském muzeu v Brně, kde pracovníci jeho Oddělení 
Pocházím z divadelní rodiny, můj otec byl více než dvacet let dramaturgem v Divadle na Vinohradech, později v Divadle za branou, matka redaktorkou časopisu Divadlo, a tak už jen pozvánka na výstavu Račte vstoupit do divadla mi udělala velikou radost. Realita předčila má veškerá očekávání. Uspořádání výstavy bylo vynikající, radostí a potěšením bylo číst si informace o jednotlivých divadelních dílech, o jejich autorech, realizátorech, o tom, co vše uvidíme a kdo to pro nás připravil, včetně anotací na další dny. Hluboce se skláním před dokonalou prací, která ukazuje a podrobně mapuje historickou a krásnou dobu divadelních cedulí a plakátů a popisuje vývoj divadla od dávných dob. Výstava si zasluhuje opravdu velké uznání.

\section{Jiří Balvín, bývalý ministr kultury}

dějin divadla měli expozici obohatit o trojrozměrné předměty ze svých fondů. Namísto toho Moravské zemské muzeum na své náklady zajistilo zpracování

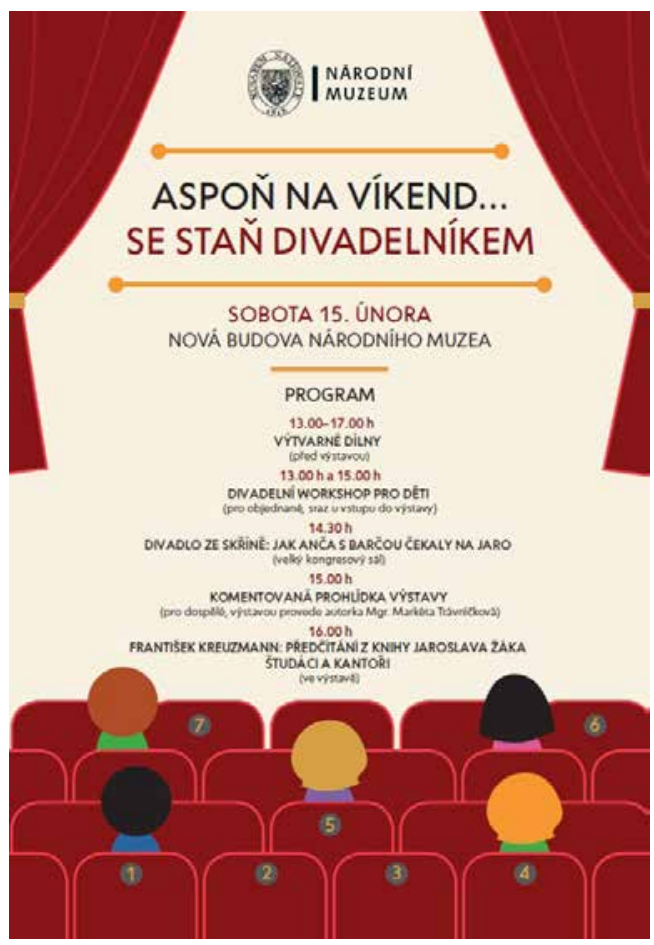

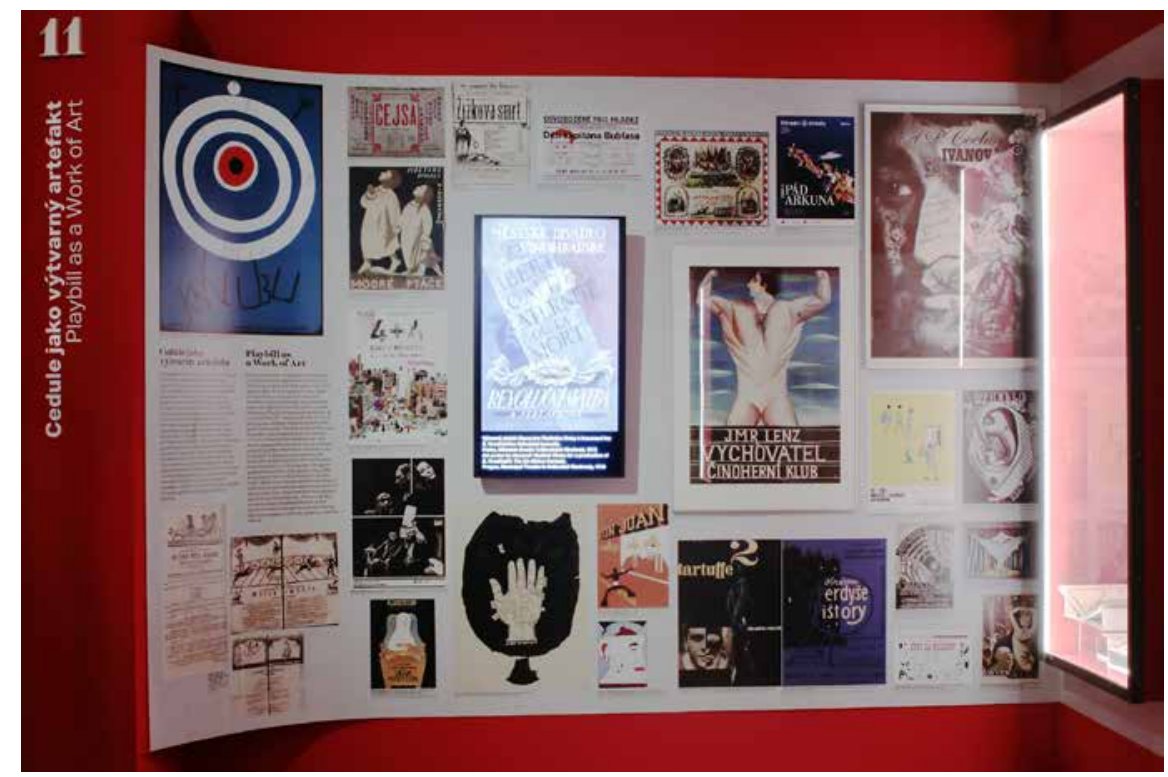

Divadelní cedule mají velký půvab pro divadelníky a archiváře, kteří z nich čerpají nedocenitelné informace. Je pravda, že se z cedulí musí umět číst a dávat si věci do souvislostí. Takže pro běžného diváka výstavy by se mohly zdát nudné, jako „obyčejné" plakáty. Domnívám se však, že na výstavě Račte vstoupit do divadla se krásně podařilo skloubit materiál troj i dvojrozměrný, a právě i zmíněné cedule zasadit do kontextu divadelní tvorby a výtvarného názoru té které doby. Výstava diváka správně zahltí, doslova obklopí různorodými divadelními dojmy a vzpomínkami - tak, jak to divadlo dokáže.

Josefina Panenková, teatroložka

počítačového programu umožňujícího virtuální prohlídku výstavy, její 3D vizualizaci, kterou budou moci všichni tři členové konsorcia (tedy Národní muzeum, Institut umění - Divadelní ústav a Moravské zemské muzeum) na svých webových stránkách bezúplatně nabízet zájemcům o výstavní projekty i dějiny českého divadla.

Stručné představení výstavy, spojené s prezentací ústředních exponátů a kvízy pro děti, připravilo $\mathrm{v}$ rámci projektu Online výstavy Národní muzeum (nm.cz/ virtualne-do-muzea/online-vystavy).

\section{Od sbírkových předmětů $k$ výstav-} ním exponátům

Divadelní cedule jsou jen v některých případech samy o sobě atraktivním výstavním 


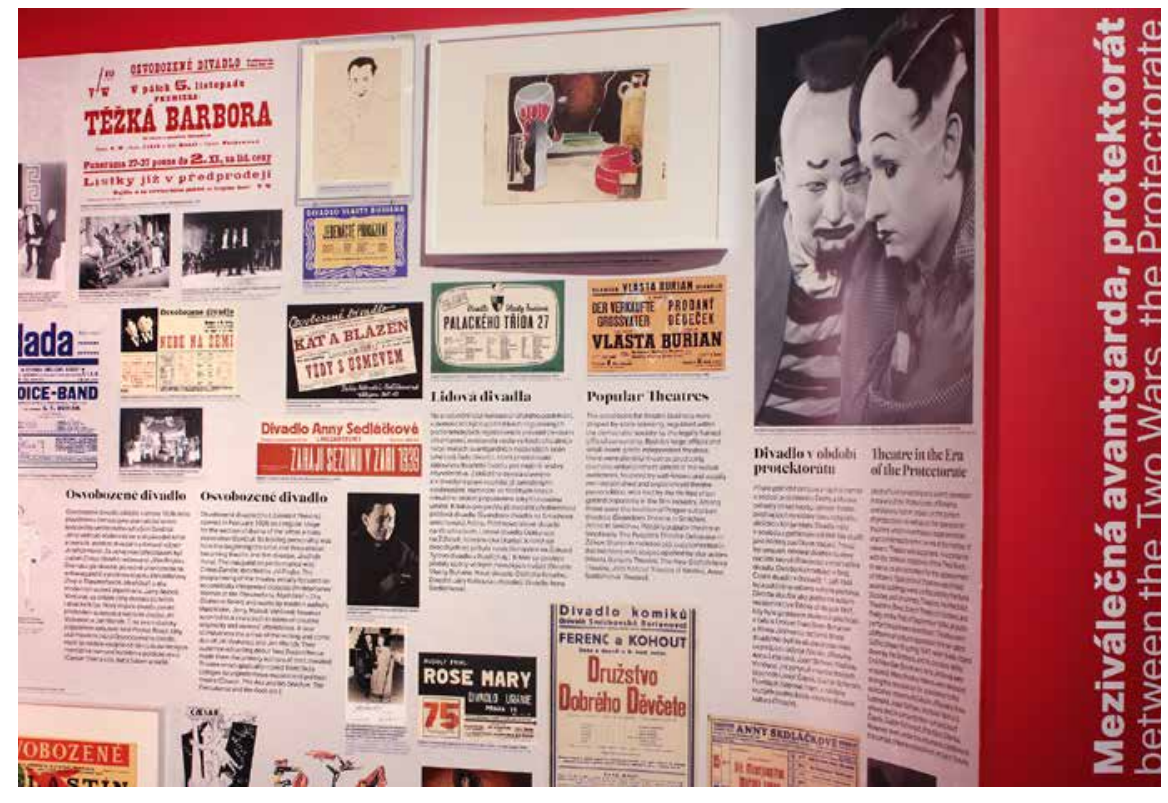

exponátem, proto jsme se snažili vždy, kdy to bylo jen trochu možné z nich fotografií, scénickým či kostýmním návrhem, režijní knihou, modelem scény, rukopisem prríslušné hry... Vedle divadelních cedulí a plakátů, které v počtu 320 kusů tvoří páteř výstavy a připomínají významné i méně významné hry a jejich inscenace $\mathrm{v}$ historii českého divadla, tak mezi nejvzácnější předměty patř́ autografy her předních českých dramatiků (Tylův Strakonický dudák a Jan Hus, Lháŕ a jeho rod Václava Klimenta Klicpery, Ženich z hladu Jana Nerudy, Maryša bratř́ Mrštíků či tzv. pařížská verze Loupežníka, na které spolupracovali oba bratři Čapkové), frak a kalamáŕ Josefa Kajetána Tyla ${ }^{10}$, klíče od Prozatímního divadla a návrh jeho opony, památky na požár Národního divadla, pokladnička, do které vlastenci sbírali peníze na jeho stavbu, kostým prvního principála z Prodané nevěsty či prvního Francka z Maryši, dětské kostýmky ze zámeckého divadla na Kačině, režijní knihy Edmunda Chvalovského, Karla Hugo Hilara, Jiř́ho Frejky. Ozdobou každé divadelní výstavy jsou výtvarné návrhy, jichž sbírka Divadelního oddělení Národního muzea obsahuje desítky tisíc a které pocházejí od nejvýrazněǰších českých výtvarných umělců, zejména meziválečných. Na výstavě představujeme dílo Josefa Čapka, Františka Zelenky, Vlastislava Hofmana, Alexandra Vladimíra Hrsky, Františka Muziky, Františka Kysely, Josefa Weniga, Aloise Wachsmanna, ze starších pak Mikoláše Alše, Františka Karla Kolára, Roberta Holzera, Jana Václava Kautského a mnoha dalších.
Račte vstoupit do divadla, zve výstava divadelních cedulí v Nové budově Národního muzea. Vstoupíte s určitou představou a jste překvapeni, jak se dá na ploše jednoho sálu vytvořit nápaditá a přitažlivá procházka více než třemi stoletími českého divadla. Základem jsou divadelní cedule s oznámeními rozmanitých představení, ale pořadatelé výstavy vás vtáhnou do př́běhu divadla také přes rekvizity, dopisy, režijní knihy či portréty... Divadelní svět nahlížíte z mnoha stran, je podtržen výtvarný podíl jak instalací návrhů scén od významných umělců (mj. František Muzika, Josef Čapek), tak velkou projekcí na filmové plátno.

Nahlédnete do repertoárů velkých kamenných divadel, kočovných společností i ochotníků. S překvapením zjištujete, kolik bylo benefičních představení, kolik významných hudebních skladatelů se na představeních podílelo... A pořád se dozvídáte novinky, třeba i o období, o němž toho možná víte poměrně dost. Víte např́klad, že po nástupu Františka Josefa na trůn v prosinci 1848 se místo představení Jana Husa dával Lortzingův Car a tesař a že slavnostní divadelní řeč připravil Karel Sabina? Víte, že plakáty pro divadelní představení navrhoval i Jiří Trnka, Libor Fára, Eva Švankmajerová nebo Pavel Brom? Tvưrci výstavy mohou být pyšní, udělali kus dobré práce pro poznání nejen českého divadla.

Věra Menclová, literární historička

Většina z téměř dvou set originálních exponátů musela před vystavením projít restaurátorskou dílnou ${ }^{11}$. U některých postačilo oprášení či drobné konzervátorské úpravy, jiné vyžadovaly náročné restaurátorské zásahy. K takovým patřily především realizované kostýmy, ale právě i divadelní cedule. Ty totiž vznikaly jako předmět denní potřeby, tištěny byly často na nekvalitní papír, nepředpokládalo se jejich zkoumání či dokonce vystavování po stovkách let. Navíc badatelský zájem o ně vždy byl a je 
enormní, což se projevilo na jejich stavu, který je často katastrofální. Restaurované a digitalizované konvoluty cedulí budou prohlášeny za takzvaný konzervační fond a nebudou nadále badatelům předkládány.

Další tisícovka sbírkových předmětů, prezentovaná v kopiích v rámci grafiky panelů nebo na elektronických obrazovkách, musela být pro potřebu výstavy zdigitalizována (naskenována či vyfotografována)

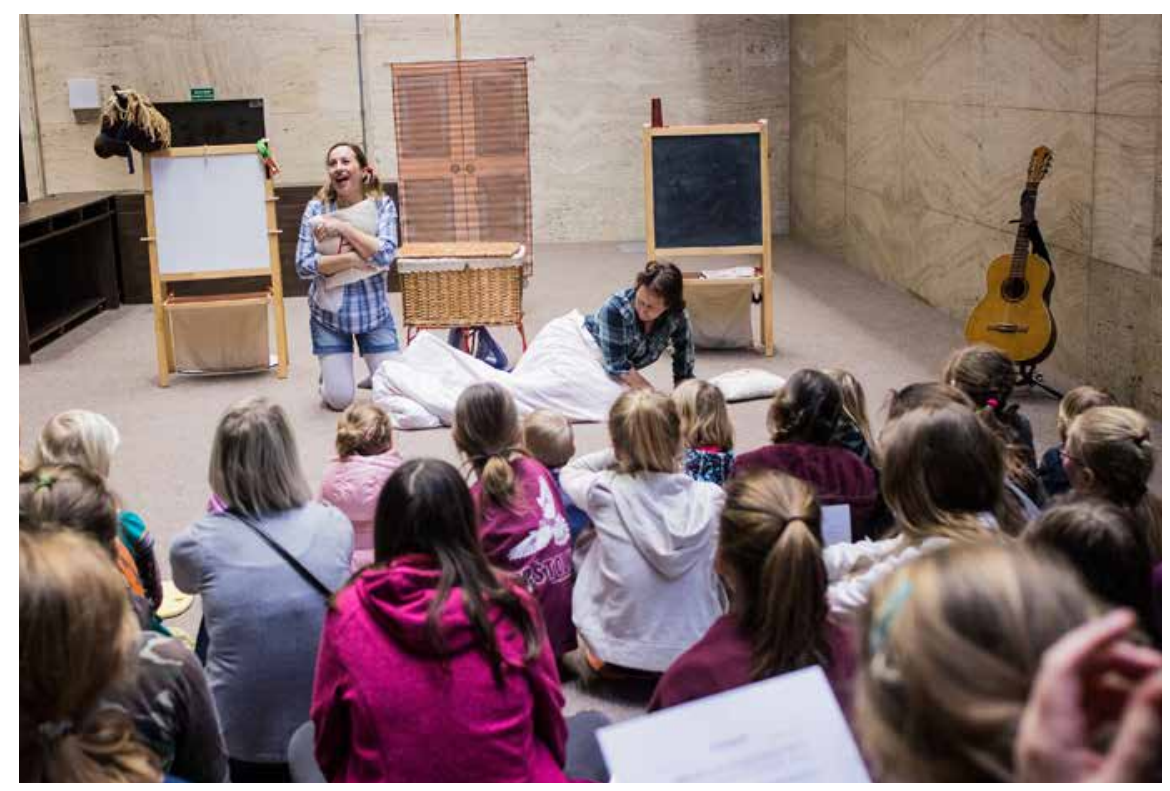

Velkoryse pojatá výstava Račte vstoupit do divadla využívající dosud nepř́liš expozičně využitý pramen - divadelní ceduli - považuji za jednu z vrcholných veřejných prezentací divadelní vědy a muzeologie posledních let $\mathrm{v}$ českých zemích. Pouze díky spolupráci všech zúčastněných institucí (Divadelní oddělení Národního muzea, Kabinet pro studium českého divadla Divadelního ústavu a Oddělení dějin divadla Moravského zemského muzea) a osobnímu nasazení hlavní kurátorky a jejího týmu se podařilo nebývale všestranným způsobem dokumentovat nejen dějiny divadelní kultury českých zemí, ale často i všudypř́tomný přesah divadelního provozu do širšího kulturního a společenského kontextu. Za nové a progresivní považuji ještě ne zcela samožrejmou skutečnost zapojení i jinojazyčných kultur a prostředí, jež rovněž utvářely českou divadelní tradici, a to nejen v kontextu pražském, ale i regionálním. Právě v tomto posledním př́ípadě je vidět, jak se vyplatila dlouhodobá aktivní spolupráce i s regionálními institucemi (archivy, muzea, divadla apod.). V zachyceném časovém úseku (od poloviny 17. století až po sklonek století 20.) reflektujícím zvolené dominantní pramenné médium bylo divácky atraktivně a odborně přesvědčivě dokumentováno několik tematických okruhů spojených s divadelním děním $\mathrm{v}$ českých zemích, neopomíjejících vedle lokální specifičnosti i jejich středoevropský kontext. Vedle problematiky sociokulturní (institucionalizace a provoz divadel coby institucí i budov, postavení hereckého i autorského personálu, publikum apod.) zde byly prezentována i „interně“ divadelní problematika (repertoár a jeho tematické zaměření, otázky dramaturgické, herecký výkon aj.) i šiřreji vztah k dalším, "sousedním“ oborům (literatura, hudba, film, pantomima, balet, loutkové divadlo, scénografie). Nepřeháním, když označím tuto výstavu za nastavenou lat'ku české divadelní vědě, a to $\mathrm{z}$ těchto ohledů: jednak kvůli svému nebývale všestrannému, a přece pronikavému tematickému i lokálním záběru, jednak kvůli expozičně přitažlivé realizaci (výběrem i instalací exponátů, včetně dětského diváka/divačky), ale i rovněž i za odborné ambice, a to vůli promýšlet zásadní (zábavnou i výchovnou) roli divadla v českých dějinách posledních tří set let.

Václav Petrbok, literární historik v ateliérech Historického muzea i několika zapůjčujících institucí. ${ }^{12}$

\section{Prostorové řešení a instalace výstavy, doprovodné programy}

Výstava byla navržena do pravého kuloáru př́zemí Nové budovy Národního muzea.
Představení jednotlivých témat bylo zasazené do stylizovaného divadla. V úvodním prostoru, divadelním foyer, byl návštěvník seznámen s pojmem divadelní cedule, rozdílem mezi cedulí, pozvánkou, návěštím, anoncí a plakátem. Dozvěděl se, čím se zabývali ceduláři a na jakých místech v Praze bývaly cedule věšeny.
12 Zde patři poděkování $v$ prípadě Národního muzea Janě Kuř́kové a Olze Tlapákové, dále Janu Cágovi, Daně Čechákové, Soně Divišové, Marcele Feretové, B. P. Keiserovi, Stanislavu Looudátovi, Oldřichu Malinovi,

Daniele Mertlové a Lud'ku Wünschovi. 
13 Napřiklad kostýmy Emy Destinnové ze Smetanovy Prodané nevěsty (1892) a Wagnerova Tannhäusera (1903), kostým Viléma Heše z Gounodova Fausta a Markétky (konec 19. století) nebo kostýmy z uvedení Prodané nevěsty v Prozatímním divadle (18661883), zapůjčené z Muzea Bedrícha Smetany.

14 Jde o autentické kostýmy z garderoby Divadla na Vinohradech, které nám je $v$ počtu 40 kusů laskavě prenechalo.

15 František Škroup, František Ladislav Rieger, Jindřich Mošna, Otýlie Sklenářová-Malý, František Adolf Šubert, Ladislav Stroupežnický, Hana Kvapilová, Vendelín Budil, Jaroslav Ježek, Anna Sedláčková.

16 Jeho veličenstvo peněžní žok, Košilatá historie o malém Robertkovi, Mazánek, Pokání starého hřišníka, Kmotr Šmodrcha, Dvě ženy a sedm kluků, Zajíc aneb Honba za mužem, Hedvábný hrb a slaměné srdce, Milosrdný bratr aneb Upalování mrtvol, 500000 čertů, Pryč s muži!, On jest hluchý...

17 Dějiny českého divadla. Soubor zvukových dokumen-

tů k I. - IV. svazku. Praha: Academia - Supraphon, 1971. Z něj byly vybrány např́klad scény $z$ opery J. J.

Fuxe Costanza et Fortezza, píseň Kde domov můj

z Tylovy Fidlovačky, Kuplet Šavličky ze Strakonického dudák téhož autora, monolog Marie Hübnerová z Čapkova Loupežníka či Eduarda

Kohouta z Shakespearova Hamleta, nahrávky z Burianova Déčka, Divadla Vlasty Buriana

a Osvobozeného divadla.

18 Připraveny byly aktivity výtvarné (vytváření vlastní scénografie, inspirované návrhy předních výtvarníkư), vědo-

mostní (přiřazování postav

k divadelním hrám a operám)

i herní (puzzle, hra s maňásky).
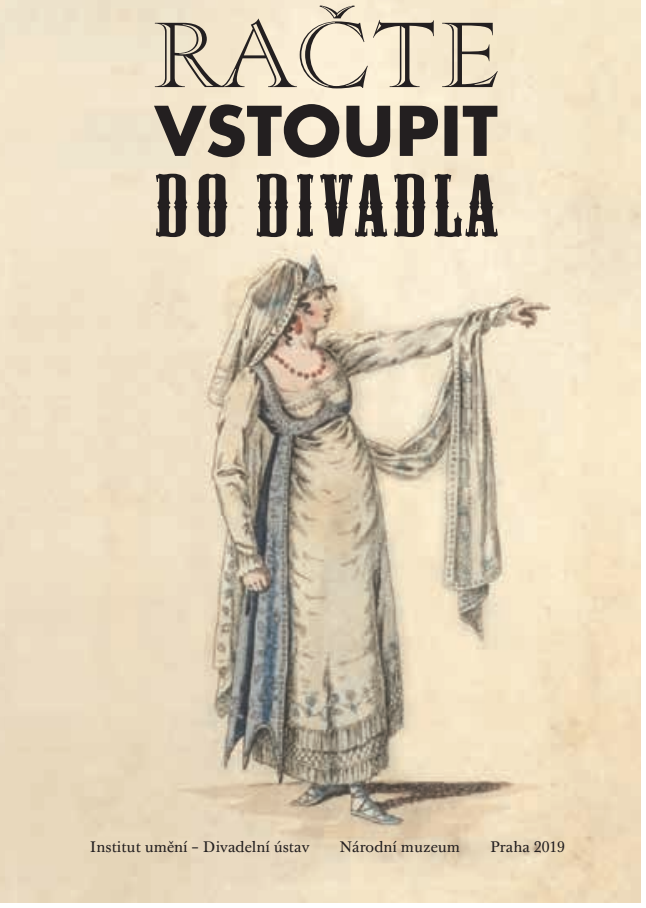

Prostor byl ohraničený třímetrovými stěnami v barvě bordeaux a ozvláštněn autentickými kostýmy ze slavných divadelních inscenací1 ${ }^{13}$. Nacházela se $\mathrm{v}$ něm i zmíněná interaktivní mapa výskytu divadelních cedulí v Čechách a na Moravě.

Z foyer vstoupil návštěvník do vlastního prostoru divadla, s hledištěm, jevištěm i zázemím. Hlediště bylo vytvořeno z lóží, které plynule ustupovaly a rozšiřovaly se. Barva stěn postupně přecházela do červené. Ve směru pohybu návštěvníka byly vždy první dvě stěny věnované textům, dvourozměrným originálním předmětům a reprodukcím, do třetí byla vsazena vitrína pro trojrozměrné předměty.

Jeviště, umístěné ve vrcholu sálu, tvořila volně stojící příčka o rozměrech $5 \mathrm{x}$ 3 metrů, na niž byly promítány výtvarné návrhy předních českých meziválečných scénografư a fotografické výjevy z inscenací tak, aby tato stěna vytvářela zároveň pozadí pro fotografování návštěvníků v kostýmech ${ }^{14}$. Za projekční stěnou se nacházela stylizovaná herecká šatna, prostor se zrcadlem pro převlečení do kostýmů.
V sále byly volně rozmístěny busty slavných českých divadelních tvưrců a interpretů ${ }^{15}$ na různě vysokých podstavcích a plakátovací sloup, na nějž byly umístěny cedule her s žertovnými názvy a dnes dávno zapomenutých. ${ }^{16}$ Zadní stěnu zdobily siluety divadelních postav. Atmosféru doplňoval akustický podkres, nahrávky ze zvukové dokumentace českého činoherního divadla 1848-1918, př́lohy akademických Dějin českého divadla. Samostatná místnost na konci sálu byla ${ }^{17}$ vyhrazena dětským návštěvníkům. Mohli se v ní seznámit s cedulemi a plakáty pro inscenace loutkových divadel i jejich aktéry - loutkami z bohatého fondu Divadelního oddělení Národního muzea. Zároveň tento prostor sloužil jako herna ${ }^{18}$ pro děti, které přišly do muzea $s$ rodiči. Pro školy - mateřské, základní i střední pořádali pracovníci edukačního oddělení Národního muzea tři speciální programy pro různé věkové skupiny. ${ }^{19} \mathrm{~V}$ sobotu 15. února 2020 děti a jejich rodiče $\mathrm{v}$ hojném počtu navštívili akci Aspoň na víkend se staň divadelníkem, v jejímž rámci se uskutečnily výtvarné dílny, představení pohádky, komentovaná prohlídka výstavy či workshop, při kterém se skupina dětí seznámila $s$ jednotlivými profesemi v divadle a pokusila se o nastudování Jiráskovy Lucerny.

\section{Ohlasy na výstavu}

Vzhledem k vypuknutí pandemie koronaviru byla bohužel výstava Račte vstoupit do divadla návštěvníkům uzavřena předčasně. Přesto do ní po dobu tř́i měsíců stihlo dorazit nebývalé množství návštěvníků, sál byl o víkendech i všedních dnech plný, uskutečnily se desítky komentovaných prohlídek pro zájemce $\mathrm{z}$ řad vysokoškolských studentů, teatrologů i muzejníků. Vedle stručných anotací ve většině českých deníků a v několika časopisech, u kterých se znovu projevil zarážející novinářský nešvar, totiž doslovné opsání tiskové zprávy ${ }^{20}$, se v i v naší hektické době, kdy je podnětů mnoho a času na kritické zamyšlení nad prací druhých málo, 
objevilo či chystá $\mathrm{k}$ publikaci několik recenzí v odborných časopisech. Dvě obsáhlejší kritiky publikovaly Divadelní noviny ${ }^{21}$. Jejich šéfredaktor Josef Herman pasuje výstavu na učebnici českého divadla a oceňuje její důsledně odborný charakter, který neuhýbá k populárním zjednodušením. Pavel Drábek recenzuje jednotlivé studie katalogu výstavy. V literárním časopise Tvar $^{22}$ vyzdvihuje Pavel Janoušek včlenění exponátů do širšího kontextu proměn českého divadla, výstavu, kterou nazývá působivou a pozoruhodnou, navrhuje jako základ potřebné budoucí pražské divadelní expozice. Vlastní recenze dále připravuje časopis Theatralia. V den, kdy byla výstava deinstalována, vyšel článek o její reálné i virtuální podobě v Lidových novinách ${ }^{23}$. Několik dalších ohlasů na naši výstavu z pera předních českých teatrologů a literárních vědců nabízíme $\mathrm{v}$ rámečcích.

\section{Použitý zdroj}

Tomáš Bílek: projektová dokumentace k výstavě, 2019.
19 1. Divadlo a já - lektorovaný program pro mateřské školy a 1. a 2. trídu základních škol; Copak je dnes na programu lektorovaný program a workshop pro žáky 3.-5. tř́dy; Komentovaná prohlídka výstavy pro 2. stupeň základních škol a střední školy. 20 Paradoxně těmi, kdo se mimo odborné kruhy okamžitě po tiskové konferenci pokusil o jakousi vlastní reflexi výstavy, byl deník Blesk a TV Barrandov. Dvě reportáže $z$ výstavy připravila Česká televize a trí rozhovory s hlavní autorkou Český rozhlas. Podrobnější článek otiskl časopis Xantipa. 21 Josef Herman: Račte vstoupit do divadla + Pavel Drábek: Račte vstoupit do dějin českého divadla. Divadelní noviny 29, 2020, č. 4, s. 10-11.

22 Pavel Janoušek: Cedule, které by potřebovaly cedule aneb Zajímavá výstava, kterou byste mohli vidět, kdybyste se o ní dozvěděli. Tvar 31, 2020, c. 6, s. 14.

23 Jana Machalická: Račte vstoupit do divadla a na internet. Lidové noviny, 8. 4. 2020, s. 7. 